DOI: $10.2478 /$ pof-2018-0030

VOLUME 10, ISSUE 3, 2018

ISSN: $2036-5438$

\title{
Inter-parliamentary cooperation and its administrators
}

by

Fotios Fitsilis*

Perspectives on Federalism, Vol. 10, issue 3, 2018 


\begin{abstract}
Parliamentary administrators have to cope with a complex and ever-changing procedural framework, as well as with conflicting demands from the policy side. Nevertheless, their role in inter-parliamentary cooperation is rather under-researched. This article focuses on the actors of Administrative Parliamentary Networks and introduces two entirely new entities: European Programmes; and networks of Parliamentary Budget Offices, which seem to have escaped scholar's attention. Administrative duties and roles are discussed in the context of inter-parliamentary cooperation and a new role is attributed to parliamentary administrators, that of the researcher. Existing findings from previous studies are put under a new light and analysed with the support of empirical data.
\end{abstract}

Key-words

Inter-parliamentary cooperation, parliamentary administration, inter-parliamentary conferences, networks, assemblies, EU affairs 


\section{Introduction}

Despite the fact that parliamentary administrations are the workhorses of complex organisations, which is what Parliaments have become in recent years, little is known about their work and impact. Actors in parliamentary administrations have many names: parliamentary officials, national representatives, secretaries, focal points, national contact points etc.; hereinafter, the terms 'administrator' and 'official' will be used interchangeably. Inter-parliamentary cooperation itself has been a field of extensive study, especially after the signing of the Treaty of Lisbon (ToL) in 2007, which provided parliaments with an active role in the shaping of the European legislative framework.

Parliamentary administrations are there to facilitate inter-parliamentary cooperation, but their role is rather under-researched. For a good reason: inter-parliamentary cooperation evolves and so do parliamentary administrations too. With often unclear job descriptions, parliamentary administrators have to cope with a complex, quasi-chaotic and ever-changing procedural framework from the one side, and conflicting demands from Members of Parliament (MPs) and high-ranking parliamentary officials from the other. Nevertheless, inter-parliamentary cooperation does take place, in the shape of systematic cooperation and communication among different parliamentary administrations, through various channels and with the use of a range of instruments.

The significance of parliamentary administrators in the fulfilment of all necessary procedures and tasks within the regime of inter-parliamentary cooperation seems to be increasing, particularly within parliamentary assemblies. ${ }^{\mathrm{I}}$ Additionally, it is well understood that administrators, contrary to elected national MPs who often serve for one or two terms only, are usually well acquainted with the ever-changing processes within the different entities of inter-parliamentary cooperation, since they may hold the same position for years. As a consequence, not only do they gain valuable field experience, but with time they also become a crucial part of the parliaments' own institutional memory. ${ }^{\text {II }}$

In the case of the European Union (EU), the member states have established a sui generis political union unlike any other in the world. The ToL provides member states' Parliaments with increased interdependency and the necessary instruments to communicate in a more efficient, consistent and cohesive manner. As a result, an EU-wide space has 
evolved that allows for dense inter-parliamentary relations not only at the political (see COSAC and other inter-parliamentary conferences) ${ }^{\mathrm{III}}$ but also at the administrative level. The latter is gradually becoming more important as new platforms for administrative cooperation, e.g. European Programmes (Twinning and research projects) and the Parliamentary Budget Office (PBO) network, are being added to the established ones; for instance, the European Centre for Parliamentary Research and Documentation (ECPRD), the InterParliamentary EU information eXchange (IPEX) and the National Parliament Representatives (NPRs) in Brussels. Both formal and informal information exchange, regular meetings and the development and operation of state-of-the-art web-based digital platforms are employed to improve interaction between national parliaments (NPs). Henceforth we shall call these networks Administrative Parliamentary Networks (APNs).

Moreover, this article considers the conduct of administrative actors as a structural component of inter-parliamentary cooperation, in its different formats. Their work has attracted attention recently and has developed into a field of studies: as a result, a typical classification scheme assigns pre-defined roles for a given set of tasks. Furthermore, the study introduces a new role, the researcher role, in order to more accurately describe the work of certain actors. Parliamentary officials who work for the inter-parliamentary cooperation turn to be active in several dimensions and with different grades of involvement. It is expected from Parliamentary Research Services (PaRS) and PBOs:

- to deliver quantitative and qualitative elaboration of information and data,

- to make forecasts based on emerging political and economic trends and

- to estimate the impact assessment of legislation,

just to mention a few aspects of their core activity. However, the work of the part of the administration that deals exclusively with inter-parliamentary cooperation, e.g. the EU Affairs Units, is often seen as mere 'paper-pushing'. In several ways, this is far from the whole reality; our introduction of the researcher role is expected to highlight further details of the actual involvement of parliamentary actors in inter-parliamentary cooperation (cf. Högenauer et al. 2016: 92). Also, the findings of existing studies are supported by further empirical evidence gathered through a series of semi-structured interviews with Hellenic Parliament (HeP) officials (see Annex for the list of interviews). ${ }^{\text {IV }}$ Hence, the added value of the present study is twofold: 
(1) It introduces two new entities in the context of inter-parliamentary cooperation, i.e. European Programmes and PBO networks, and

(2) It introduces a new administrative role for parliamentary administrators, i.e. the researcher role.

The paper is structured as follows: The next section presents a review of the existing literature on parliamentary administrations, followed by a detailed discussion of the APNs in the EU (section 3). Administrative support of other existing inter-parliamentary formats is shown in section 4, which opens the discussion on the roles and responsibilities of administrative actors as displayed in section 5. The last section presents the conclusions and an outlook for future research (section 6).

\section{Literature review}

\subsection{General literature}

It has been suggested that NPs are the 'Losers or Latecomers' of Europeanisation (Maurer and Wessels 2001). The 'deparliamentarisation debate' is currently being reconsidered as parliaments fight back to tighten governmental scrutiny in EU matters through procedural reforms, while MPs are getting more active in using available control mechanisms (Raunio 2009: 328). The idea of cooperation between parliaments is neither new, nor is this concept only to be found within the European continent (Cutler 2001; Kissling 2011; Rocabert et al. 2014). ${ }^{\mathrm{V}}$ When discussing inter-parliamentary cooperation within the EU it is always advisable to have in mind the underlying institutional framework. This has been provided in the form of guidelines by the Conference of the Speakers of the EU Parliaments. ${ }^{\mathrm{VI}}$ With an apparently exploding number of entities of inter-parliamentary cooperation, Fromage (2016) posed important questions on their sustainability, visibility and practicability. As there is evidence of proliferation of inter-parliamentary cooperation entities, it might be necessary to start thinking about some form of rationalisation, although this question falls beyond the scope of this paper.

Furthermore, the link between national and supranational administrations is of particular importance: Knill (2001) underlined previous observations on the 'fusion' of supranational and national bureaucracies (see also Wessels and Rometsch 1996), but they failed to point out specific interactions between national and European administration and 
proceeded with a comparative assessment of national administrations while implementing certain European policies. This inter-link between supranational and national bureaucracies was also attempted by Miklin (2011), who investigated the effect of inter-parliamentary cooperation on power relations within the Austrian parliament. The latter work belongs to a rather limited circle of contributions referring to the effects of inter-parliamentary cooperation on NPs.

\subsection{Literature on parliamentary administrations}

Parliamentary administrations do not exist per se; they are there to facilitate and support parliamentary operations. As parliaments adjust to confront changes, administrations change with them. Parliamentary administrations have been the subject of study for several decades, though not in a systematic and structured way. In addition, they have traditionally been studied within their own realm, the NP, thus isolated from external influence. This trend seems to have shifted with the publication of new studies on the contribution of parliamentary administrations to the challenges of EU integration, which sparked new interest for their 'external' action and impact.

Until recently, most studies on administrative personnel in parliaments have been either descriptive or concentrate on their legislative work. 1981, for instance, was a good year for the study of parliamentary administrations, as significant contributions to three major European Parliaments were published: on the German Bundestag (Blischke 1981), the French parliamentary assemblies (Campbell and Laporte 1981), and the House of Commons (Ryle 1981). On the other side of the Atlantic, Hammond reviewed the literature on legislative staffing research in the U.S. Congress and noted that the theoretical viewpoint may vary: role theory, organisation theory, exchange theory, etc. (Hammond 1984: 302).

The significance, and complexity, of the European Parliament (EP) has drawn scientific attention. Pegan studied the legislative staff in the EP and emphasised the lack of empirically driven research on the study of parliamentary administrations (Pegan 2011: 5). Neunreither (2002), among others, investigated the parliamentary administration of the EP in a broader study of the impact of unelected assistants to the legislative function. In a survey dedicated to parliamentary staff in EP, Egeberg et al. (2013) discussed the possibility that parliamentary administrators may affect the content of political decisions in analogous 
way to governmental officials. On the parliament of Luxembourg, Spreitzer (2013) assessed the activity of the EU affairs administration, which is counted among the most active when it comes to subsidiarity and proportionality control, suggesting that this was to be attributed to political motivation rather than efficient administrative procedures. However, the most comprehensive work so far on parliamentary administrations in the EU remains the contribution by Högenauer et al. (2016) as it manages to provide state-of-the-art knowledge on administrative actors within the EP, NPs and 'Transnational Bureaucratic Networks in the EU' at the same time.

Apart from major parliaments and this time outside the European context, there are only sporadic notes on parliamentary administrations to be found, which include the case of Algeria (Amrani 2008). Amrani views inter-parliamentary cooperation mainly from the capacity building point of view, i.e. as an opportunity for the Council of the Nation to improve its organisation, operation and quality of service towards MPs. In this sense, the concept of a manual with 'case law of parliamentary administration' is introduced.

In the academic literature, there is an increasing volume of studies on Parliamentary Research Services (PaRS) as well as on Parliamentary Budget Offices (PBO). Miller et al. (2004) investigated the parts of parliamentary administration that constitute sources of parliamentary information for a number of countries, e.g. Libraries, PaRS, Institutes and PBOs. More recently, a PaRS survey in Central Europe and the Western Balkans' parliaments has been published and, recently, the impact of PaRS in the strengthening of parliamentary institutions has been investigated in a comparative analysis which included the EP, the Austrian Parliament, the National Assembly of Serbia and the Hellenic Parliament (Papazoski 2013; Fitsilis and Koutsogiannis 2017). So far, PaRS and PBO have been investigated in isolation from other parliamentary functions or processes, i.e. interparliamentary cooperation. Thus, a part of this contribution is dedicated to the discussion of the role of PaRS and PBO networks and their administrators in inter-parliamentary cooperation.

\section{Administrative Parliamentary Networks in the EU}

\subsection{National Parliament Representatives}


Early signs of administrative cooperation between NPs and the EP can be found in the establishment of national offices at the EP premises in the first couple of decades of European integration (Pegan and Högenauer 2016: 147). These may be considered as forerunners of the NPRs in the 1990s. Of all the APNs, the network of the NPRs is the one that has been studied in most detail by several publications from the same cluster of researchers (Högenauer et al. 2016; Neuhold and Högenauer 2016; Neuhold and Högenauer 2013). Liaison officers, as they are also called, constitute an informal but powerful administrative network, which is strategically positioned inside the EP premises in Brussels, to communicate closely with EU institutions and agencies and stay updated on major policy issues and activities. Interestingly enough, their offices are located on the same floor of the same building of the EP and not in their permanent national delegations, although there are exceptions to that rule. The German representatives, for instance, also have their own external premises, while the Belgian ones serve in their offices in the NP (interview 2). Neuhold and Högenauer (2016: 252) summarise the main functions of this network as follows: 'to enable effective scrutiny within a parliament and to enable the effective use of the EWM [Early Warning Mechanism] collectively'.

The number of delegates is generally changeable, purely dependant on national interests and each NP's practices. However, after Lisbon, there is usually one NPR per national parliamentary chamber present, meaning that most bicameral parliaments have two NPRs in place, but there are also member states which might have more: Cyprus (unicameral) has two, Belgium, like France, has a total of four NPRs, two per chamber, including a deputy for the NPR from the Sénat, a move that should be analysed with caution, since the Belgian Sénat is situated just a few blocks away. The latest data shows that each EU member state has at least one NPR in Brussels, thus surpassing the 40 mark for the first time. ${ }^{\text {VII }}$

There is no general rule that determines how long NPRs will be sent to Brussels. During their stay they remain closely connected with other NPRs on a daily basis. On the one hand, this high degree of socialisation within the network supports informal information exchange, a significant feature when it comes to effective coordination in the framework of the EWM (ibid.: 250-251); but, on the other hand, NPRs follow different working patterns marked primarily by their parliament's interests, thus preventing the network from becoming more than the mere sum of its members. In the course of further 
development of the discussed APN, NPs could agree to develop a common job description for the NPR positions along with guidelines and a code of conduct.

In order for the Hellenic Parliament to fulfil its oversight role, the Greek NPR monitors EP activities and drafts reports on the content of plenary sessions, committee work and the various conferences. Reporting takes the form of special notes or weekly reports to the Directorate of European Affairs, with a summary of the major topics

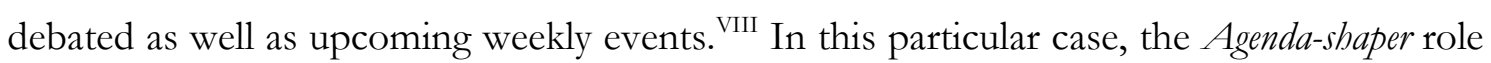
may be attributed to the NPR. In addition to these notes, the work of the NPR may include:

- coordination with homologues on subsidiarity issues (hence the coordinator role),

- gathering of information on the parliamentary dimension of the Council Presidency (Czachór 2013),

- informing on the conclusions of EU Council summits,

- answering questionnaires by other parliaments, think tanks, universities, etc.

The network organises itself through regular Monday Morning Meetings (MMMs), where NPRs gather to discuss issues of common concern. MMMs have a structured agenda, which includes policy briefings from EP, EC or Council officials, topics of common interest, alerts for subsidiarity compliance under the EWM and even issues outside the spectrum of EU activities (interview 2). The COSAC secretariat also takes part in the MMMs. This close relation between the COSAC secretariat and the NPRs becomes more evident in cases where NPRs also assume a position in the EU rotating presidency (ibid.). EP officials, unless invited, are not allowed to participate, which could be seen as a persistent effort to preserve the independency of the NPRs (ibid.).

The discussion on subsidiarity issues and lobbying activities against certain legislative EU may reveal national priorities and, therefore, constitute a de facto alert system that informs NPs on political incentives or tendencies (ibid.). This clearly speaks for attributing a Coordinator role to the NPRs. MMMs and the daily exchange of information among NPRs allow for informal updates on topics of interest for NPs. Such informal communication is rare among administrative actors in digital networks, such as IPEX, as electronic communications may be monitored or logged. 


\subsection{IPEX}

The InterParliamentary EU information eXchange, IPEX, is a unique concept in interparliamentary cooperation because of its multifaceted nature. It comprises an information web portal, a databank with documents concerning the EU, including reasoned opinions from NPs and a calendar of inter-parliamentary cooperation meetings and events in the EU. This information is by default publicly available via the web portal. The decision for its creation derived from the Conferences of Speakers in Rome (2000) and in The Hague (2004). ${ }^{\text {IX }}$ At the center of IPEX there is a cooperative platform, which allows for multilevel access according to the rights granted by the system administrator (interview 9). Knutelská (2013) has been among the first to study the role of IPEX in the scrutiny of EU affairs. Cooper sees IPEX as the 'virtual third chamber' of the EU. At the same time, he assesses that IPEX did not have a substantial role in the coordination that was necessary prior to the issuing of the yellow card to the Monti II Regulation (Cooper 2011: 20; Cooper 2015).

IPEX is governed by a board which is appointed by the Meeting of the Secretaries General (SGs) of the EU Parliaments. According to the relevant IPEX guidelines, as approved by the meeting of the SGs in Rome (2015), the board does not have a fixed composition and consists of administrators representing, (1) the parliamentary troika of the Conference of Speakers, (2) the NP holding the Presidency of the Council of the EU during the first semester of the year in which the Board takes office, (3) the EP and (4) NPs that 'wish to participate [...]'. Participation of the EP is not surprising given that the EP contributes significantly to the IPEX budget, which is co-financed by NPs (Pegan and Högenauer 2016: 159; interview 9). The COSAC, the ECPRD, the European Commission and the Council take part in board meetings, but other organisations may also be invited to participate by the board chair. The IPEX board convenes 2-3 times a year depending on the agenda and the significance of the topics therein (interview 9). The presence in board meetings of other inter-parliamentary cooperation entities, such as COSAC and ECPRD, is an excellent way for coordinating actions, thus avoiding possible delays and wasting of resources, without the need of an omnipresent governing organ, e.g. the Conference of Speakers, and constitutes a good practice that could find widespread application. In a recent development, COSAC encouraged its secretariat and the IPEX board to 'cooperate 
towards increasing the interconnection between the COSAC website and the IPEX platform'.

The underlying database contains a number of parliamentary and other Europeanrelated documents intended to facilitate the flow of information between NPs, and particularly for the scrutiny of EU draft legislation. The workforce behind IPEX is a network of national experts, the IPEX correspondents. The national correspondents are responsible for the frequent updating of the IPEX database with information from their national Parliaments. Hence, IPEX correspondents cooperate with national contact points from other inter-parliamentary cooperation entities, particularly with their respective NPRs in Brussels, in cases of EU legislative scrutiny (ibid.). NPs may also use the network of IPEX correspondents to obtain missing information on inter-parliamentary cooperation issues. From this perspective, IPEX resembles the function of the ECPRD network. However, the network of the NPRs seems more 'fit for purpose' due to its inherent proximity and permanent availability. Each NP usually appoints up to two IPEX Correspondents. The IPEX correspondents constitute an administrative network which holds annual meetings for information exchange and capacity building purposes. Their usual roles are those of administrative assistant and coordinator. IPEX also employs an Information Officer situated at the EP in Brussels, which underpins the existence of a permanent secretariat.

At the 20-21 February 2017 Meeting of the SGs, a digital strategy for the further development of IPEX was adopted, which also incorporates the result of a consultation with the IPEX Correspondents. The digital strategy is implemented through a 3-year Work Programme. According to the relevant document this very first Work Programme set three priorities: 'Enhancing the IPEX network', 'Strengthening the promotion of IPEX' and 'Improving the IPEX digital system'. ${ }^{\mathrm{XI}}$ User conferences constitute a new concept within the IPEX environment. These have an informal character and a non-specified frequency. They have been created in order to gain independent feedback from IPEX users on the platform's operation and development. The first user meeting took place in 2015 in Copenhagen and the next one is scheduled to take place in Stockholm in 2018 (ibid.).

\subsection{ECPRD}


The European Centre for Parliamentary Research and Documentation (ECPRD) is a network established in 1977 to strengthen inter-parliamentary cooperation among parliamentary administrations. Only parliamentary administrators may participate, thus constituting a pure APN. Its members go well beyond the EU and include: (1) the EU, (2) the Parliamentary Assembly of the Council of Europe (CoE) and (3) the Parliamentary Assemblies of the Member States of the EU and the CoE. This is a total of 66 parliamentary chambers from 54 countries, while there are also parliaments with observer status (ECPRD 2016: 4). ${ }^{\mathrm{XII}}$ According to its statutes (article 10), it is financed by the EP and the Parliamentary Assembly of the CoE (ibid.: 25). By decision of the SG of each member parliament, one national ECPRD correspondent, or simply correspondent, is appointed. Deputy correspondents may also be appointed (ibid.: 24).

The ECPRD network organises an annual conference. It is governed by an executive committee, which comprises two co-directors, appointed by the SGs of the EU and the $\mathrm{CoE}$, respectively, and five correspondents elected by the annual conference (interview 4). Out of the latter, each one of four coordinators is entrusted with one of the main subjects of ECPRD: (1) Economic and Budgetary Affairs, (2) Information and Communication Technologies in Parliaments, (3) Libraries, Research Services and Archives and (4) Parliamentary Practice and Procedure (ibid.). Coordinators are responsible for organising the ECPRD seminars, usually two seminars per year and per subject. Coordinators define the agenda for the seminars, relying on personal preferences, trends and forecasts for the specific subject. These seminars promote interaction between correspondents and constitute a useful platform for the exchange of good practice, and the avoidance of bad practices (ibid.).

The network has a secretariat with two administrators, who again are drawn from the EP and the Parliamentary Assembly of the CoE, respectively. The main tasks of the secretariat are to support the co-directors in the preparation of the annual conference as well as to perform all administrative tasks necessary for the network to operate, including keeping the ECPRD database operational and up-to-date (ibid.). The agenda of their annual conference is decided by the executive committee. Apart from the annual conference, the committee meets four times per year, in order to program and effectively coordinate ECPRD activities (ibid.). ECPRD parliaments may also host seminars to 
present and discuss their organisational structure, recent developments or policies and to exchange relevant good practices (ibid.).

The most significant activity of the ECPRD network takes place online via its cooperative digital platform, which also includes a resource database containing the ECPRD questions and answers archive. The platform may be used by parliamentary administrations for the retrieval of past questions or, with the consent of the SG, for requesting information by other parliaments on virtually any given matter of political or parliamentary relevance. There are 28 different general topics that can be addressed, the most popular being those relating to parliamentary practice (40\%), information to projects (17\%) and social affairs and health issues (14\%) (ECPRD 2017: 6). Recently, the platform underwent extensive refurbishment to be used on mobile devices (ibid.: 7). This form of parliamentary cooperation using a centralised digital platform, rather than the usual peerto-peer scheme, has a voluntary character and seems to have flourished over the past years. From 2003 to 2015 the number of ECPRD requests has grown steadily, from below 100 comparable requests in 2003 to 287 in 2015 (ECPRD 2016: 9). A request may be sent to a specific set of parliaments or to all ECPRD members; an interesting trend shows that parliaments prefer to target their requests towards a narrow set of recipients, rather than sending them out to all of them.

Parliaments that receive a request are given a certain period of time to respond. Latest data show that $72 \%$ of the responses are collected within the designated period and $85 \%$ up to five days past the deadline (ECPRD 2017: 5). As mentioned, participation in this information exchange is voluntary and there are no consequences for those who refrain from responding. However, practice has shown that parliaments tend not to respond to requests from 'repeat offenders', as a form of informal retaliation measure to 'discipline' those who frequently ignore incoming requests (interview 4).

ECPRD actors assume several roles (Högenauer et al. 2016) when exercising their duties. Correspondents and their deputies mainly act as administrative assistants, while the co-directors, the members of the secretariat as well as the coordinators take on the coordinator role. Finally, the researcher role may be attributed to the extent the aforementioned actors participate in the elaboration of internal reports, final summaries or deeper scientific studies. ${ }^{\text {XIII }}$ In contrast to IPEX, ECPRD requests, responses and final summaries are only available to ECPRD members. The issue of openness was also tackled 
by Pegan and Högenauer (2016: 159) in a short description of IPEX and ECPDR under the title 'information and documentation networks'. Nevertheless, in cases where information is of non-confidential nature or based on the elaboration of publicly accessible data, specific contents of the ECPRD database could be made public after a period of embargo.

\subsection{PBO Networks}

PBOs support the (financial) oversight function of parliaments and are part of the Independent Fiscal Institutions (IFI) which are independent public institutions with a mandate to critically assess, and in some cases provide non-partisan advice on, fiscal policy and performance' (von Trapp and Nicol 2017: 1). It is the independence of such offices that is of particular importance; as Anderson discusses the establishment of non-partisan, independent and objective analytic budget units is a means to counterbalance information superiority of the executive (in Stapenhurst et al. 2008: 138). PBO officials enjoy the scientific freedom to address issues around state budget implementation and fiscal discipline, which is one of the key elements for the Researcher role to be attributed (see also section Errore. L'origine riferimento non è stata trovata.). In addition, the Global Network of Parliamentary Budget Officers (GNPBO) has developed guidelines for PBOs, which also include a code of conduct. ${ }^{\text {XIV }}$

In the EU, the first efforts for cooperation among the IFIs were initiated in 2013 by the Directorate General for Economic and Financial Affairs (DG ECFIN) of the European Commission (EC) and took the form of informal annual, and post-2015 biannual meetings. Later, in the third meeting of the EU IFIs in 2015, the EU Network of Independent Fiscal Institutions (EUNIFI) was established, which serves as a platform for capacity building and exchange of good practices (interview 8). Today, the network includes members from 24 EU member states. ${ }^{\mathrm{XV}}$ The network has a parliamentary administrator as permanent secretary and is currently negotiating the financing and the location of its permanent secretariat (ibid.). EUNIFI also interacts with the OECD Network of Parliamentary Budget Officials and Independent Fiscal Institutions (OECD PBO) by attending its annual meetings which take place since 2009.

EUNIFI is not exclusively a network for PBOs. In this regard, one needs to note that the number of PBOs in the EU is still small, but is steadily growing. In the last years the 
following parliaments have established a PBO: the Hellenic Parliament in 2010, the Austrian Parliament in 2012 (Budgetdienst), the Italian Parliament in 2013 (Ufficio parlamentare di bilancio, Upb) and the House of the Oireachtas (Ireland) in 2017. To these may be added the Hungarian Fiscal Council, established in 2008, which is administratively linked to the National Assembly, and the Office for Budget Responsibility in the United Kingdom, established in 2010, which is accountable to both the Government and Parliament. ${ }^{\text {XVI }}$ It can be no coincidence that all these PBOs have been established in the post-Lisbon era. Hence, it is safe to conclude that their number is expected to increase.

As PBOs continue to gain in significance, the networks of officials, i.e. EUNIFI, OECD PBO and GN-PBO, will continue to expand. In a field which is characterised by a high degree of diversity, inter-networking activities will become even more important in the future. On the other hand, the development of digital cooperative platforms, e.g. www.epbo.org, has the potential to leverage the usually scarce parliamentary resources in a more efficient way (Chohan 2013: 18-19).

\subsection{European Programmes}

Over decades, the EU has invested considerable resources in scientific research, i.e. the Framework Programmes for Research and Technological Development, as well as technical assistance towards candidate states and members of the European Neighbourhood Policy through the Twinning instrument. European Programmes enjoy broad visibility, but they have not yet been the subject of analysis in the context of interparliamentary cooperation, as attempted in this paper. The term European Programmes characterises research and EU Twinning projects. Both present a further opportunity for inter-parliamentary cooperation; an opportunity that attracts little attention in the literature. Regarding EU-funded research, only few EU parliaments seem to have identified the possibilities that emerge through application of recent technologies in the parliamentary domain.

Within the context of the 7th Framework Programme (FP7), the Hellenic and Austrian Parliaments have been active in research consortia, which may also be described as European research networks (Fitsilis et al. 2017). ${ }^{\text {XVII }}$ The Seimas (Lithuania) has been also studied in the course of the LEX-IS project (ibid.). Such networks may also include a variety of non-parliamentary actors, e.g. universities, research institutes, civil society 
organisations, small and medium sized enterprises etc. and the researcher role can be clearly attributed to the parliamentary administrators involved. Building on the know-how gained by its participation in FP7 research projects, particularly in the areas of eParticipation, Policy Modelling and Social Network Analysis, the Hellenic Parliament has been awarded a series of EU-funded IPA (Instrument for Pre-Accession Assistance) Twinning contracts (ibid.).

The EU Twinning instrument has been used for two decades to support beneficiary, i.e. candidate or partner, countries to strengthen their administrative capacity. ${ }^{\text {XVIII }}$ Tulmets (2005) analysed the impact of the Twinning instrument within the European Enlargement Policy. In parliamentary Twinning projects, the implementing partners are EU parliaments as well as relevant mandated bodies. To date, several such projects have been implemented within the IPA and the European Neighbourhood Policy region. However, general numerical data on EU Twinning projects are not available and may be the scope of further dedicated study.

The Hellenic Parliament has been awarded three Twinning projects in Serbia, Turkey and Albania, respectively: (1) IPA-2011/SR 11 IB OT 01 'Strengthening the Capacities of National Assembly of the Republic of Serbia towards EU Integration', (2) IPA-2014/TR 14 IB JH 03 'Empowerment of the Role of Parliament in the Protection and Promotion of Human Rights by Strengthening the Administrative Capacity of Parliament', (3) and IPA2014/AL 14 IPA JH 0116 'Further Strengthening the Assembly of Albania in the context of EU Accession'. The project in Albania lasted 12 months (May 2017-May 2018), while the one in Turkey has not been contracted yet. The Italian Parliament is junior partner in both those projects. The parliamentary Twinning project in Serbia was successfully concluded in 2014 (January 2013 - November 2014). More than 100 experts on parliamentary affairs from 10 countries participated in the project and cooperated with numerous MPs and administrators from the National Assembly of Serbia, governmental institutions such as ministries and agencies, independent state bodies and representatives of civil society. ${ }^{X I X}$ Due to their involvement in core parliamentary procedures within the beneficiary institution, Twinning experts may assume the role of analyst or advisor. In several cases, e.g. when conducting comparative studies, the researcher role may be also attributed.

\begin{tabular}{|l|c|c|c|c|c|}
\hline Entities & NPRs & IPEX & ECPRD & PBO & European \\
\hline
\end{tabular}




\begin{tabular}{|c|c|c|c|c|c|}
\hline Roles & & & & Network & Programmes \\
\hline $\begin{array}{c}\text { Administrative } \\
\text { Assistant }\end{array}$ & $\bullet$ & $\bullet$ & $\bullet$ & $\bullet$ & \\
\hline Coordinator & $\bullet$ & $\bullet$ & $\bullet$ & & \\
\hline Analyst & & \multirow{2}{*}{\multicolumn{3}{|c|}{$\begin{array}{l}\text { Roles related to interaction with national } \\
\qquad M P s \& \text { committees }\end{array}$}} & $(\bullet)^{*}$ \\
\hline Advisor & $(\bullet)^{*}$ & & & & $(\bullet)^{*}$ \\
\hline Agenda-shaper & $\bullet$ & & & & \\
\hline Researcher (new) & & & $\bullet$ & $\bullet$ & $\bullet$ \\
\hline
\end{tabular}

Table 1: Signature roles for parliamentary administrators in APNs

The above table summarises administrators' basic roles in parliamentary networks. Other administrative positions, such as the permanent member of the COSAC Secretariat, has also drawn some attention (Pegan and Högenauer 2016: 151-152). Högenauer et al. (2016: 58-62) have given a more thorough presentation of this position and a comparison with the NPR. As for the rest of the administrative positions in the scrutiny of EU affairs, the interested observer has to rely on a rather limited set of relevant contributions (Högenauer et al. 2016: 69-89; Högenauer and Christiansen 2015).

\section{Administrative support of existing inter-parliamentary formats}

Besides APNs, multi-level inter-parliamentary cooperation in the EU is also demonstrated in other established formats such as Inter-parliamentary Meetings and Assemblies, Inter-parliamentary Conferences (IPC) and Conferences and Meetings of the Parliamentary Leadership. ${ }^{\mathrm{xx}}$ When dealing with IPC and Inter-parliamentary Meetings and Assemblies, administrators of NPs seem to share a common set of characteristics, the most significant of which belong to the following triplet: (1) knowledge of procedures, (2) knowledge of the basic agenda and surrounding topics and (3) knowledge of executive mentality and organisational culture (interviews $3 \& 5$ ). ${ }^{\mathrm{XXI}}$ The core tasks of the relevant parliamentary administrators are: the secretarial support for national delegations, the synthesis of information around the topical agenda, the exchange of good practices and the preparation or drafting of amendments. Other tasks, though with a lower, unspecific frequency, also include occasional language support for the national delegates (interviews 2, 
$3 \& 5$; Fromage 2016: 768). Compared to other entities of inter-parliamentary cooperation, e.g. NPRs or IPEX correspondents, a significant difference is that administrators tend to remain secretaries for much longer (interviews $1 \& 5$ ). ${ }^{\text {XxII }}$

With time, these administrators naturally develop personal networks with secretaries from other NPs and with the members of the permanent secretariat. This high degree of socialisation with conference/assembly officials may push forward a political agenda in a more effective way (interview 5). However, in some cases, it may also have a negative effect, when administrators tend to operate within a closed circle of NPs' stakeholders, thus solely constituting the institutional memory of their parent organisation (interview 1). Without proper dissemination of information, e.g. an electronic document management system in the NP, a broad circle of officials for de-/briefing or the organisation of internal seminars for the exchange of information on inter-parliamentary cooperation, NPs are likely to face partial or even total loss of institutional memory in cases of retirement, internal rotation or the abrupt exit of the administrator. Within the Hellenic Parliament, the issue is tackled through planning of a training pipeline for new administrators (interviews 1 $\& 5)$.

From the above it may be concluded that administrators, who are entrusted with IPCs and Inter-parliamentary Meetings, take on two basic roles after Högenauer et al. (2016). First, they take up the administrative assistant role since they summarise and forward information. For this, they may conduct literature searches and refer to existing archived material. In some cases, access to information from relevant governmental units, ministries or agencies, is sought. Second, they equally adopt the advisor role since they certainly provide content-related advice, and drafts of amendments or other types of policy documents, prior to debates. In several cases, those parliamentary administrators operate in a comparable way to MPs' scientific advisors, thus they may be also characterised as quasiscientific advisors. Occasionally, the agenda-shaper role may apply. The question, whether the researcher role may also be attributed, is related to the fulfilment of the criteria mentioned in section Errore. L'origine riferimento non è stata trovata., and needs to be answered on a case by case basis. The analyst role has not been visible while evaluating the set of interviews and might be only occasionally present. Ultimately, administrators from those two classes seem to be slightly more versatile than those working for APNs, who seem to specialise in a certain range of tasks. 
The Conference of the Speakers and the Meetings of the SGs are regulatory organs of inter-parliamentary cooperation in the European context. ${ }^{\text {xIII }}$ Both entities meet on an annual basis. In contrast to classification types mentioned earlier, the entities that deal with the parliamentary leadership are presented separately from COSAC, which is classified among the other IPCs (cf. Högenauer et al. 2016: 61-62). The Conference of the Speakers sets political priorities and coordinates inter-parliamentary activities with the operational support of the Meeting of the SGs. The latter plays an important role in the implementation of political decisions. The Meetings of SGs sit astride political and administrative inter-parliamentary cooperation. In these meetings both the ECPRD and IPEX correspondents as well as the complete IPEX board are appointed. Furthermore, SGs are usually the ones who legally bind their parliaments as signatories on European Programmes' contracts. SGs, as heads of parliamentary administrations but also vested with the power to take politically binding decisions, do not seem to fit into the model of roles as presented above. ${ }^{\mathrm{xxI}}$

While both entities have the entire parliamentary administration at their disposal, administrative support is neither systematised at the national level, nor is a permanent secretariat established in order to systematically overview inter-parliamentary cooperation activities, e.g. as in the COSAC case. Administrators supporting this class are usually political advisors and although they frequently interact with the permanent parliamentary administration, the discussion on their impact falls out of the scope of the present study and may constitute a separate research topic.

\section{Parliamentary administrators and their roles}

\subsection{Classification of parliamentary actions}

Within the inter-parliamentary cooperation regime, administrators take on a number of positions which require different sets of skills. Hence, a typology of roles has been gradually derived to classify administrative actions as accurately as possible. Högenauer and Christiansen (2015) assign three functions to the parliamentary administration:

- the 'coordination function', e.g. for the NPRs in Brussels,

- the 'information management function', as administrators often appear as ‘information brokers' and 
- the 'Pre-selection function', when administrators may filter EU documents, thus having the ability to guide the agenda.

This distinction in functions and roles of administrators in not new. Provan, ${ }^{\mathrm{XxV}}$ in his analysis of the administrative support towards Members of the EP, distinguished between 'technical-administrative assistance', which is organisational in nature, 'technical-substantive assistance', which includes legal advice and support with procedures and drafting, 'research assistance', which refers to the provision of options and impact assessment to the policy makers and 'political assistance', when working with policy issues and political coordination (Neunreither 2002: 55). Another typology of roles, developed for the U.K.'s mid-level bureaucracy, is to be found in Page and Jenkins (2005: 60-75), who differentiate between a 'production role' (creation of policy-related documents), a 'maintenance role' (policy management) and a 'service role' (advisory services).

Out of these roles, only the production and service roles are likely to be found in the parliamentary context (Högenauer and Neuhold 2013: 8). The latter proceed with a definition of four roles for parliamentary administrators, each responsible for a different set of tasks and with increasing involvement around information management in the scrutiny of EU affairs: 'administrative assistant', when forwarding and/or summarising information, 'analyst', when providing legal/procedural advice and opinion drafts following debates, 'coordinator', when coordinating between NPs or between chambers in a bicameral parliament and 'advisor', when providing content-related advise and ex-ante opinion drafts (ibid.: 10). This concept is further enriched with a fifth role: 'agenda-shaper', when administrators preselect documents for parliamentary debates (Högenauer et al. 2016: 94). Undoubtedly, given current requirements, any given parliamentary administrator rarely corresponds to a single role and might include a set of roles or might even 'combine different elements from the different sets of categories.' Högenauer and Neuhold (2013: 17).

The present study leads to the extension of the roles mentioned above by a sixth one, that of the researcher, which is presented in the next section. This new role is closely linked to the use of scientific methods, the adoption of a code of conduct and, most importantly, the publication of elaborated material. The definition of a researcher role seems inevitable when considering that inter-parliamentary cooperation also includes newly formed networks of PBOs as well as EU Programmes, which both rely on the work of scientific 
advisors in the service of financial oversight and of parliamentary research, e.g. comparative analyses, documentation and exchange of good practices, digital transparency, civic engagement etc.

\subsection{Researcher: A new role for administrators?}

Based on the line of thought developed in previous section, the researcher role is added to the five roles of parliamentary administrators that have been presented by Högenauer et al. (2016). The scientific dimension within parliaments has previously been identified; Egeberg et al. (2013: 511) mentioned that 'Giving professional, scientific and technical advice is a major part of the work for a majority of both EP-secretariat officials and administrative staff of the political groups'. Further, the participation of researchers from PaRS in the scrutiny of EU affairs has been already shown by Högenauer and Christiansen (2015: 119). Similar considerations are valid for the officials who work in the PBOs. The researcher role may equally be attributed to them too.

At the same time, there may be administrators across the parliamentary organisation (also from the EU Affairs units) who contribute to the implementation of Horizon 2020 research or to a parliamentary Twinning project, which are by default both complex and manifold EU instruments. In the case of Twinnings, administrator's assignments may include broad searches for information sources, the development and evaluation of surveys and questionnaires, the carrying out of structured interviews, and policy analysis and the derivation of recommendations. As for the participation in research programmes, the specific tasks depend on the research topic. But, if EU Affairs administrators take on a researcher role when operating within the context of European Programmes, do they have a researcher role too when operating within their designated entities of inter-parliamentary cooperation? In order to adequately respond to that question, the (parliamentary) researcher role needs to be defined in more detail.

Parliamentary research has been a field of study by the Inter-Parliamentary Union (IPU) and the International Federation of Library Associations and Institutions (IFLA). These have issued guidelines for the development of $\mathrm{PaRS}$, which contain key attributes for researchers (IPU and IFLA 2015: 27). From subsequent evaluation we derive a total of four major characteristics for the researcher role. Researchers are specialists; therefore, they must have a certain field of specialisation. While general or broader knowledge is certainly 
important, research is usually conducted within narrow and well defined scientific fields. A researcher possesses in-depth knowledge and the skills to apply recognised and approved research methodologies.

As technology and methods evolve, researchers need to have access to capacity building activities, if not life-long training programmes, in order to be aware of new developments in the field, to expand their skill-set or acquire new skills and techniques. However, the defining characteristic of the researcher role is the need for publication of research results, which is also stipulated in the European Code of Conduct for Research Integrity (ibid.: 28; ALLEA 2017: 6). The reporting of results is not an optional feature, but a generic element of the researcher role, which ensures that research is transparent and thus open to independent assessment. Reporting also constitutes a major difference between the researcher role and the (scientific) advisor role. The latter role is frequently assigned to parliamentary administrators who work with politicians, be it parliamentary groups or MPs.

When it comes to linking the researcher role to EU Affairs administrators in the interparliamentary cooperation regime, one needs to apply the aforementioned definition. Hence, (1) the field of specialisation is given, e.g. EU Affairs, (2) knowledge and application of research methodologies is present, but only in certain cases, e.g. when a parliamentary administrator is drafting a reasoned opinion (interview 2), (3) access to training is guaranteed, e.g. see specialised seminars by inter-parliamentary assemblies or the national schools of government, (4) but the publication of results does not always seem to be feasible. The latter is well understood in situations when confidentiality is a prerequisite, such as in cases when revealing critical intra-parliamentary affairs, tactical or strategic goals could lead to the weakening of negotiation positions. In these cases, publication in the form of internal reports could be considered. This issue is closely related to the scientific freedom a researcher should enjoy.

Within the bureaucracy of the EU Affairs units, administrators follow strict internal reporting rules, which rarely leave space for scientific publications or reporting (interviews 6 \& 7); this leads de facto to a limited academic presence. In order to overcome the aforementioned shortcomings (see points $2 \& 4$ of the researcher role definition), we propose a set of recommendations: first, the adoption of guidelines for administrators from EU affairs units, similar to the ones the IPU and IFLA have drafted for PaRS, as well as a code of conduct. Second, one could think of developing an EU Network of EU affairs 
administrators, similar to the African Network of Parliamentary Staff (RAPP). ${ }^{\text {Xxv }}$ Finally, the institutional evolution of administrators in EU affairs can be achieved through an assimilation of the researcher role and its related attributes. The latter constitutes one of the most significant findings of this study.

\section{Conclusions and outlook}

The role of parliamentary administrators in inter-parliamentary cooperation is often underestimated and recent studies have started to reveal its true dimension. This article discussed the contribution of parliamentary administrators to the operation, and strengthening, of inter-parliamentary cooperation. A domain initially limited to experts from the EU Affairs units, e.g. departments, directorates etc., inter-parliamentary cooperation is now rapidly extending to other parliamentary domains of operations, such as parliamentary research and financial oversight. A set of new entities of interparliamentary cooperation has been introduced for the first time, i.e. European Programmes and PBO networks. These constitute purely administrative networks and are classified under APNs, which is an active and developing field, and more research is necessary to further highlight less visible entities like the PBO network.

In their daily routine, administrators take on a number of roles, be it purely administrative, advisory, analytic or other. Our study of parliamentary administrations has led to the development of the concept of the researcher role. In the context of interparliamentary cooperation, the attribution of the role to EU Affairs officials has been discussed and a number of conditions and recommendations have been provided. Most importantly, the researcher role has the potential to re-shape operations of parliamentary administrators in the context of inter-parliamentary cooperation. Targeted professional training would be necessary to strengthen their capacities, e.g. to develop new sets of skills for the scientific elaboration of reports and to adapt in a developing digital environment. The development of a dedicated administrative network and the adoption of a code of conduct could also contribute towards the same direction. Ultimately, strengthened administrative capacities could result in an increase of the relative power of parliamentary officials and potentially influence the voting behavior of MPs. Elsewhere it is mentioned that administrator roles may alter depending on the occasion. In challenging earlier 
research, our analysis suggests that fixed roles could be attributed to specific administrative position (cf. Högenauer and Neuhold 2013). This implies that job description patterns for parliamentary administrators need to be clear, a practice followed by large intergovernmental organisations, a practice that could lead to an increased level of understanding and cooperation among homologues.

Additional findings suggest that Information Communication Technology (ICT) tools increasingly support inter-parliamentary cooperation operations. With the developing penetration of ICT technologies, even less formal assemblies without permanent secretariats could increase their visibility, sustainability and, consequently, their significance, thus elevating their status. Also, the development of virtual fora could facilitate a large part of coordination activities and increase cooperation between parliamentary administrations prior to the plenary sessions of assemblies, particularly when a permanent secretariat is not present. $^{\text {XXVII }}$ With the exception of IPEX, most inter-parliamentary cooperation entities have yet to develop a comprehensive digital strategy. The Conference of the Speakers, as the coordinator of inter-parliamentary cooperation in the EU, could promote a digital strategy towards integration of the existing digital platforms and services.

\footnotetext{
* Head of Department for Scientific Documentation and Supervision, Scientific Service, Hellenic Parliament.

I For instance, the Council of Europe (CoE), the Inter-Parliamentary Union (IPU) and the North Atlantic Treaty Organization (NATO) hold seminars exclusively for parliamentary administrators. These seminars aim to further educate and prepare parliamentary officials for specific conduct within the organisations, e.g. through frequent updates on structural or procedural changes. At the same time such seminars offer opportunities to contact foreign colleagues and to exchange potentially significant information.

II The term 'institutional memory' usually describes the collective knowledge and learned experiences of a group of professionals within an organisation (here the National Parliaments). Naturally, parliamentary officials who work with inter-parliamentary cooperation entities have knowledge of the underlying complex procedures as well as of good practices.

III COSAC stands for the Conference of Parliamentary Committees for Union Affairs of Parliaments of the European Union. Other inter-parliamentary conferences to date are the Common Foreign Security Policy and the Common Security and Defense Policy (CFSP/CSDP) conference and the Interparliamentary Conference under Article 13 of the Treaty on Stability, Coordination and Governance (TSCG).

IV The author would like to thank Margarita Flouda, Head of General Directorate for International Relations \& Communication, Paraskevi Karastergiou, Head of Directorate for International Relations and International Organisations and Anastassia Fragou, Head of Directorate of European Affairs and Bilateral Issues for fruitful discussions and suggestions. Particular thanks are due to Despoina Fola and Marina Kousta for their valuable support throughout the project.

$\mathrm{V}$ The entities of inter-parliamentary cooperation on the global scale are called International Parliamentary Institutions (IPIs). While reviewing the literature on IPIs, it becomes evident that the examination of networks of parliamentary administrators and well as the study of their role in inter-parliamentary cooperation is neglected, possibly due to objective difficulties to collect empirical data on the global scale. In the European context, such studies are beginning to emerge to fill a gap in the relevant literature, thus promoting our understanding of the conduct of often non-visible actors of inter-parliamentary cooperation. VI A list of inter-parliamentary cooperation entities is contained in the Hague guidelines (2004), which have been amended by the Lisbon guidelines (2008). Interestingly, while the essence of the guidelines as well as the
} 
total number of inter-parliamentary cooperation entities does not seem to alter, some distinct changes between the 2 versions are still to be found. First, IPEX and ECPRD are 'degraded' to 'instruments of cooperation'. Second, there is a reshuffling of the entities within the remaining list: COSAC is moved up to second position, while the meetings of the sectoral committees are moved down to $4^{\text {th }}$. Finally, the item 'Simultaneous debates in interested parliaments' is replaced by 'Joint meetings on Topics of common interest'. These changes also represent a drift in the perception of the Conference of EU Speakers of how inter-parliamentary cooperation should be structured. Also, in the Stockholm Guidelines (2010), the Conference of Speakers stated its will to 'oversee the coordination of interparliamentary EU activities' (article 2).

VII This value is calculated based on on-line information from the COSAC website: http://www.cosac.eu/permreps/ (accessed 16/12/2017).

VIII In the period from September 2015 to July 2016 the Greek NPR office drafted 66 reports and notes on issues related to EP plenary activities (18), EP committees (13), inter-parliamentary meetings (12), topics of national interest (12) and highlighted topics discussed at the MMMs (11).

IX According to the IPEX guidelines as approved by the meeting of the Secretaries General in Rome (2015). The IPEX website (http://www.ipex.eu/) was launched on 30 June 2006 according to the guidelines prepared by the Danish Presidency for the Conference of EU Speakers concerning the calendar for interparliamentary cooperation (2011).

$x$ Conclusions of the 58th COSAC in Tallinn, 27 and 28 November 2017.

XI More information may be found in the IPEX Work Programme 2017-2020, which was adopted by the IPEX Board in Bratislava on 19 May 2017.

XII According to the ECPRD website: https://ecprd.secure.europarl.europa.eu (accessed 19/12/2017) the parliaments with observer status are the Knesset of Israel, the House of Commons and the Senate of Canada, and the Senado and the Cámara de Diputados of Mexico.

XIII Less than $25 \%$ of requests are concluded with a final summary, despite the relevant requirement in the internal guidelines for comparative requests.

XIV GNPBO issued its draft guidelines for 'Operationalizing a Parliamentary Budget Office' at its 2015 Annual Meeting.

$\mathrm{xV}$ The value is calculated based on data from the EU IFI website: http://www.euifis.eu/ (accessed 15/12/2017). According to it, fiscal authorities from Belgium, Croatia, Czech Republic and Poland do not participate in the EUNIFI.

XVI The OECD Independent Fiscal Institutions Database (2017) has been consulted: http://www.oecd.org/gov/budgeting/OECD-Independent-Fiscal-Institutions-Database.xlsx (accessed 15/12/2017).

XVII The mentioned contribution analysed data from five EU-funded projects: LEX-IS, +Spaces, NOMAD, ARCOMEM and METALOGUE.

XVIII Twinning projects are forms of administrative cooperation addressed to extra-EU countries. The cooperation between EU parliamentary administrations is therefore an indirect consequence of these projects.

XIX Experts from Greece, Austria, France, Germany, UK, Belgium, Slovakia, Poland, Hungary and Montenegro took part in the activities of the parliamentary Twinning project in Serbia. 752 MPs, administrators and representatives from the civil society have been trained during 40 capacity building activities.

xx The class 'Conferences and Meetings of the Parliamentary Leadership' includes the Conference of the Speakers and the Meetings of the Secretaries General.

XXI Of course, the mentioned characteristics are rather general and may also be attributed to almost any of the previously discussed actors of inter-parliamentary cooperation.

XXII Although plausible, there is no further empirical evidence to support this statement and more research could be conducted to spot differences between administrators.

XXIII The European Conference of Presidents of Parliament (ECPP) of the CoE and the Conference of the Speakers of Parliaments of the South-East European Cooperation Process may also be counted in this class. ECPP is closely related to the Parliamentary Assembly of the Council of Europe and is organised with its support.

XxIV While there are cases where Secretaries General belong to the permanent staff, in several other cases they are elected officials and should not to be counted among administrators. Secretaries General are vested 
with the power to represent their respective parliaments even in political topics, a privilege that administrative personnel usually does not enjoy.

Xxv James L.C. Provan has been EP Vice-President from 1999-2004.

xxvI The idea for the creation of RAPP, http://www.rappafrik.org/, came up in 1995, but it was created only in 2003.

XXVII The presence of digital fora parallel to the organisation of committee meetings is generally suggested as a good practice, even though previous attempts, such as in the case of the IPEX digital fora, have not been successful and have been terminated.

\section{References}

- $\quad$ ALLEA, 2007, The European Code of Conduct for Research Integrity, ALLEA - All European Academies, Berlin.

- Amrani Hafnaoui, 2008, The challenges of Parliamentary Administration in African countries: The case of Algeria, Inter-Parliamentary Union.

- Blischke Werner, 1981, 'Parliamentary staffs in the German Bundestag', Legislative Studies Quarterly, VI(4): 533-558.

- Campbell Stanley and Laporte Jean, 1981, 'The Staff of the Parliamentary Assemblies in France', Legislative Studies Quarterly, VI(4): 521-531.

- Chohan Usman, 2013, 'Canada and the Global Network of Parliamentary Budget Officers', Canadian Parliamentary Review, Autumn 2013.

- Cooper Ian, 2011, 'A “virtual third chamber” for the European Union? National parliaments after the Treaty of Lisbon', in ARENA Working Paper, 7.

- Cooper Ian, 2015, 'A yellow card for the striker: national parliaments and the defeat of EU legislation on the right to strike', Journal of European Public Policy, XXII(10): 1406-1425.

- $\quad$ Cutler Robert M., 2001, 'The Emergence of International Parliamentary Institutions: New Networks of Influence in World Society', in Smith Gordon S. and Wolfish Daniel (eds), Who Is Afraid of the State? Canada in a World of Multiple Centres of Power, University of Toronto Press, Toronto, 201-229.

- Czachór Zbigniew, 2013, 'Parliamentary dimension of the Polish presidency', Środkowoeuropejskie Studia Polityczne, III(3): 7-29.

- ECPRD, 2016, Activity Report 2014 - 2015, European Centre for Parliamentary Research and Documentation, Brussels.

- $\quad$ ECPRD, 2017, Interim Activity Report October 2016 - September 2017, European Centre for Parliamentary Research and Documentation, Brussels.

- $\quad$ Egeberg Morten, Gornitzka Åse, Trondal Jarle and Johannessen Mathias, 2013, 'Parliament staff: unpacking the behaviour of officials in the European Parliament', Journal of European Public Policy, XX(4): 495514.

- Fitsilis Fotios and Koutsogiannis Alexandros, 2017, 'Strengthening the Capacity of Parliaments through Development of Parliamentary Research Services', in $13^{\text {th }}$ Workshop of Parliamentary Scholars and Parliamentarians, Wroxton.

- Fitsilis Fotios, Koryzis Dimitris, Svolopoulos Vasilios and Spiliotopoulos Dimitris, 2017, 'Implementing Digital Parliament Innovative Concepts for Citizens and Policy Makers' in Nah Fiona FuiHoon, Tan Chuan Hoo (eds), HCI in Business, Government and Organizations. Interacting with Information Systems, HCIBGO 2017, Lecture Notes in Computer Science, 10293, Springer, Cham.

- $\quad$ Fromage Diane, 2016, 'Increasing Inter-Parliamentary Cooperation in the European Union: Current Trends and Challenges', European Public Law, XXII(4): 749-772.

- $\quad$ Hammond Susan Webb, 1984, 'Legislative staffs', Legislative Studies Quarterly, IX(2): 271-317.

- Högenauer Anna-Lena and Christiansen Thomas, 2015, 'Parliamentary Administrations in the Scrutiny of EU Decision-Making' in Hefftler Claudia, Neuhold Christine, Rozenberg Olivier, Smith Julie (eds), The Palgrave Handbook of National Parliaments and the European Union, Palgrave Macmillan, London, 116132. 
- Högenauer Anna-Lena and Neuhold Christine, 2013, National Parliaments after Lisbon: Administrations on the Rise?', Observatory of Parliaments after the Lisbon Treaty, online paper no. 12/2013.

- Högenauer Anna-Lena, Neuhold Christine and Christiansen Thomas, 2016, Parliamentary Administrations in the European Union, Palgrave Macmillan, London.

- IPU and IFLA, 2015, Guidelines for parliamentary research services, Inter-Parliamentary Union (IPU) and the International Federation of Library Associations and Institutions (IFLA).

- $\quad$ Kissling Claudia, 2011, The legal and political status of international parliamentary institutions, Committee for a Democratic U.N., Berlin.

- Knill Christoph, 2001, The Europeanisation of National Administrations, Patterns of Institutional Change and Persistence, Cambridge University Press, Cambridge.

- Knutelská Viera, 2013, 'Cooperation among national parliaments: an effective contribution to EU legitimation?', in Crum Ben and Fossum Erik (eds), Practices of interparliamentary coordination in international politics, ECPR Press, Colchester, 33-49.

- Maurer, Andreas and Wolfgang Wessels (eds), 2001, National Parliaments on their Ways to Europe. Losers or Latecomers?, Nomos, Baden-Baden.

- Miklin Eric, 2011, 'Inter-Parliamentary Cooperation in EU Affairs and the Austrian Parliament: Empowering the Opposition?' in ECPR General Conference, Reykjavik.

- Miller Robert, Pelizzo Riccardo and Stapenhurst Rick, 2004, Parliamentary Libraries, Institutes and Offices: The Sources of Parliamentary Information, World Bank Institute, Washington D.C.

- $\quad$ Neuhold Christine and Högenauer Anna-Lena, 2016, 'An information network of officials? Dissecting the role and nature of the network of parliamentary representatives in the European Parliament', Journal of Legislative Studies, XXII(2): 237-256.

- Neuhold Cristine and Högenauer Anna-Lena, 2013, 'Administrators Networking EU Affairs? The Role of Parliamentary Officials in Inter-Parliamentary Coordination and Control', in 13th EUSA Biennial Conference, Baltimore.

- Neunreither Karlheinz, 2002, 'Elected legislators and their unelected assistants in the European Parliament', Journal of Legislative Studies, VIII(4): 40-60.

- Page Edward C. and Jenkins William Ieuan, 2005, Policy bureaucracy: Government with a cast of thousands, Oxford University Press, Oxford.

- Papazoski Zuzana, 2013, Development of Parliamentary Research Services in Central Europe and the Western Balkans, National Democratic Institute for International Affairs. Washington, D.C.

- Pegan Andreja, 2011, 'European Parliament and Its Administration: What Do We Know and Where Do We Go Next?', in EGPA Annual Conference, Bucharest.

- Pegan Andreja and Högenauer Anna-Lena, 2016, 'The Role of Parliamentary Administrations in Interparliamentary Cooperation', in Nicola Lupo and Cristina Fasone (eds), Interparliamentary Cooperation in the Composite European Constitution, Hart Publishing, Oxford, 147-164.

- Raunio Tapio, 2009, 'National Parliaments and European Integration: What We Know and Agenda for Future Research', Journal of Legislative Studies, XV(4): 317-334.

- Rocabert Jofre, Schimmelfennig Frank and Winzen Thomas, 2014, 'The Rise of International Parliamentary Institutions? Conceptualization and First Empirical Illustrations', in ECPR Joint Sessions, Salamanca.

- $\quad$ Rometsch Dietrich and Wessels Wolfgang (eds), 1996, The European Union and member states: towards institutional fusion?, Manchester University Press, Manchester and New York.

- $\quad$ Ryle Michael T., 1981, 'The Legislative Staff of the British House of Commons', Legislative Studies Quarterly, VI(4): 497-519.

- $\quad$ Spreitzer Astrid, 2013, 'Administrating EU affairs in the Luxembourgish parliament', in $7^{\text {th }}$ ECPR General Conference, Bordeaux.

- $\quad$ Stapenhurst Rick, Pelizzo Riccardo, Olson David M. and von Trapp Lisa, 2008, Legislative Oversight and Budgeting. A World Perspective, The World Bank, Washington, DC.

- Tulmets Elsa, 2005, 'The introduction of the Open Method of Coordination in the European Enlargement Policy: Analysing the impact of the new Phare/Twinning Instrument', European Political Economy Review, III(1): 54-90. 
- von Trapp Lisa and Scherie Nicol, 2017, 'Designing effective independent fiscal institutions', Organization for Economic Co-operation and Development - OECD.

\section{Annex}

The following interviews were conducted between 27 October and 4 December 2017:

1. Interview with official from the General Directorate for International Relations and Communication, 27/10/2017

2. Interview \#1 with clerk from the Directorate of European Affairs and Bilateral issues, 1/11/2017

3. Roundtable with officials from the Directorate of European Affairs and Bilateral issues, 3/11/2017

4. Interview with ECPRD deputy representative, 3/11/2017

5. Roundtable with officials from the Directorate of International Relations and International Organizations, 7/11/2017

6. Interview \#2 with clerk from the Directorate of European Affairs and Bilateral issues, 23/11/2017

7. Interview with official from the Directorate of European Affairs and Bilateral issues, 23/11/2017

8. Interview with PBO official, 29/11/2017

9. Interview with deputy IPEX correspondent, 4/12/2017. 